\title{
Boa noite, e boa sorte: determinantes da demissão de ministros envolvidos em escândalos de corrupção no primeiro governo Dilma Rousseff
}

\author{
Cletiane Medeiros Araújo \\ Saulo Felipe Costa \\ Ítalo Fittipaldi
}

\section{Introdução ${ }^{1}$}

O início do segundo governo de Dilma Rousseff (PT) sofreu uma onda de escândalos de corrupção envolvendo políticos, funcionários públicos e empresários, que circundam particularmente o denominado Caso Petrobras. Desde meados de 2013, algumas denúncias foram se intensificando e motivaram a criação de uma Comissão Parlamentar de Inquérito (CPI) por parlamentares da oposição, com o intuito de manter a estatal sob uma ampla investigação. Todavia, essa não é a primeira onda de denúncias do governo Dilma, os 17 primeiros meses do primeiro mandato, em 2011, foram notoriamente marcados por escândalos envolvendo parte do seu corpo ministerial.

Para o caso brasileiro recente, em ambas as ondas, a mídia adquiriu centralidade através da contínua publicização das informações acerca de tais escândalos. Nesse sentido, a visão corrente observa que em um ambiente democrático que detém uma mídia independente é possível compreendê-la como peça funcional ao exercício da accountability horizontal e social ${ }^{2}$, haja vista que pode cumprir papel fiscalizatório entre poderes e instituições, dando voz à sociedade civil organizada e aos movimentos sociais nas distintas áreas da esfera pública ${ }^{3}$.

A ideia é que os escândalos políticos, especificamente os associados à corrupção, emergem na agenda pública como resultado positivo das construções midiáticas, revestindo-se como uma espécie de "cão de guarda" da sociedade ${ }^{4}$. Ou seja, em um

\footnotetext{
${ }^{1}$ Agradecemos aos pareceristas anônimos de Opinião Pública pelas sugestões e contribuições dadas a uma versão anterior deste artigo. Contudo, as falhas e omissões remanescentes são de nossa inteira responsabilidade.

2 Os conceitos de accountability política utilizados neste artigo seguem os termos de O'Donnell (1998).

3 Nesse limite, parte da literatura aponta que a via de responsividade apenas pelo controle vertical não é suficiente, em função da baixa capacidade por parte do eleitor em responsabilizar os malfeitos dos políticos quando estes continuam sendo eleitos, o que sugere um quadro de reduzida memória institucional e desinteresse cívico pela esfera pública (Przeworski e Stokes, 1995; O'Donnell, 1998; Peruzzotti e Smulovitz, 2002).

4 Assim, segundo essa abordagem, essa forma de controle pode agir como determinante para a sobrevivência da elite político-administrativa em um ambiente democrático, em que a vida política de um
} 
ambiente democrático, quanto maior for a intensidade do escândalo político maior será a investida na responsabilização de tal denúncia de corrupção, conforme é sugerido pela literatura. Não obstante, há de se reconhecer que esse enfoque analítico destaca fundamentalmente o papel da mídia nesse processo de responsividade democrática, o que permite que se (re)atualize uma agenda de pesquisa sobre essa questão, que é per se o grande desafio da democracia representativa contemporânea.

Este artigo busca estimar em que medida os escândalos de corrupção impactam na probabilidade de responsabilização dos agentes públicos denunciados nos respectivos escândalos. Seu foco analítico visa contribuir para a compreensão desse fenômeno destacando que o papel de publicizador investido pelos meios de comunicação bem como o gerenciamento presidencial da coalizão incidem na probabilidade de responsividade sobre os ministros envolvidos em tais escândalos.

O artigo está dividido em três seções, para além desta Introdução. Na primeira seção, será discutida a accountability política: o papel do escândalo político. A seção seguinte, "Apresentando os dados", mostra uma análise descritiva sobre os escândalos e discute, através do ferramental econométrico, os determinantes para a demissão de um ministro denunciado em escândalo de corrupção. Finalmente, a terceira seção expõe as considerações finais do artigo.

\section{Accountability política: o papel do escândalo político}

A relação estreita entre corrupção e política não é novidade. A conjugação dessas duas dimensões remonta às análises interessadas na explicação de mecanismos e instituições que fazem parte de um conceito mais amplo de democratização. Nas modernas democracias representativas a dimensão da qualidade democrática se torna tema central, uma vez que o processo de democratização foi largamente instituído em diversos países no mundo (Shin, 2007; Diamond, 2002; O'Donnell, 1998; Weffort, 1992; Reis, 1988; Sen, 1999; Vianna, 2002; Moisés, 2008). Dentre as distintas dimensões (procedimentais e substantivas) com as quais a qualidade democrática pode variar, Diamond e Morlino (2004), e.g, destacam a capacidade de accountability política e responsividade enquanto peças fundamentais no vínculo entre representantes e representados. Ou seja, "accountability is the obligation of elected political leaders to answer for their political decisions when asked by voters of constitutional bodies" (Diamond e Morlino, 2004, p. 25).

representante depende da maioria de votos nas urnas e, consequentemente, os custos reputacionais importam. Ao organizar e mobilizar demandas e denúncias contra atos ilegais na esfera política, tais investidas podem obrigar o governo (representantes e burocratas) a responder pública e oficialmente às petições da sociedade civil organizada. A exposição pelos meios de comunicação das mazelas governamentais possibilita que o debate público não seja monopolizado por agências do governo. 
BOA NOITE, E BOA SORTE: DETERMINANTES DA DEMISSÃO DE MINISTROS ENVOLVIDOS EM ESCÂNDALOS DE CORRUPÇÃO

A partir dessa perspectiva os conceitos atinentes às possíveis formas de accountability adquirem centralidade nos estudos da área ${ }^{5}$, particularmente sobre as discussões de accountability vertical, horizontal e societal (O'Donnell, 1998). Accountability vertical ou eleitoral é exercida através do voto retrospectivo do eleitor para os governantes eleitos, os quais podem ser punidos ou premiados a depender da performance do seu governo (Powell, 2004). Todavia, a existência dessa forma de controle não garante per se a eficácia da responsividade dos governos, mesmo em democracias maduras. No caso de novas democracias, algumas características do próprio processo de democratização, tais como "sistemas partidários pouco estruturados, alta volatilidade de eleitores e partidos, temas de política pública pobremente definidos e reversões políticas súbitas" (O'Donnell, 1998, p. 29), são percebidas como janelas de oportunidades para a prevalência do comportamento rent-seeking ${ }^{6}$ por parte da elite político-administrativa.

Por seu turno, accountability horizontal é exercida através de uma rede de agências estatais que se controlam e se equilibram mutuamente. Nesse sentido, para tentar obter eficácia nessa forma de controle, deve-se ater a algumas condições, a saber: a) papel de fiscalização dos partidos políticos da oposição; b) Tribunais de Contas preventivos e profissionalizados; c) Judiciário independente e profissionalizado; d) mídia e instituições de pesquisas independentes e confiáveis.

No tocante à accountability social ou societal, parte-se do pressuposto de que se trata de uma forma de controle com o intuito de monitorar o comportamento da elite político-administrativa, através do caráter essencialmente denunciativo das ações ilegais praticadas por essa elite, mantendo um canal de ligação junto à atuação de agências de accountability horizontal. Tais mecanismos de controle são exercidos pela sociedade civil organizada, com o apoio, sobretudo, dos meios de comunicação.

Nesse ponto, a democratização de um país está associada à progressiva inclusão dos distintos grupos na esfera política, em que o papel da mídia adquire relevância, sobretudo em contextos cuja personalização do candidato é necessariamente mais importante que o partido político ao qual é filiado ${ }^{7}$. Portanto, não é irrelevante questionar em que medida a accountability política pode ser reforçada pela exposição dos desvios de atores políticos reportados pela mídia.

\footnotetext{
5 A accountability política traz em sua configuração problemas também diferenciados de graus de responsividade e de qualidade democrática (Moreno, Crisp e Shugart, 2003; Cox e McCubbins, 2001; Melo, 2007; Diamond e Morlino, 2005).

${ }^{6} \mathrm{O}$ conceito de rent-seeking foi elaborado por Tullock (1967) e posteriormente desenvolvido por Krueger (1974).

7 Ao estudar as "metamorfoses do governo representativo", principalmente no que tange às mudanças na representação política a partir do século XIX na Europa, Manin (1997) identifica distinções da representação de outrora para a contemporânea, dada a presença dos meios de comunicação de massa. Ao utilizar o conceito de democracia de público, Manin aponta que esse conceito resulta da transformação do sistema representativo, haja vista que os meios de comunicação influenciam substancialmente no cálculo político do eleitor através da formação da opinião pública.
} 
Para tanto, é necessário compreender a dinâmica em torno da construção do escândalo político, como e por que alguns malfeitos se transformam em escândalos particularmente, escândalo de corrupção - amplamente repercutidos pelos meios de comunicação enquanto outros não se tornam públicos ${ }^{8}$. A questão da visibilidade é peça fundamental para compreender a diferença entre a ação ilegal e o escândalo. Como objeto de interesse deste artigo, a corrupção é definida pela obscuridade do uso indevido da função pública para benefício privado ${ }^{9}$; quando essa ação passa a ser revelada ao público e gera forte reação social, pode ser considerada um escândalo de corrupção ${ }^{10}$.

Quanto à lógica de desdobramento de um escândalo, Thompson (2002) sugere uma estrutura de ações sequenciais num limite temporal. O estágio inicial é caracterizado pelo vazamento de informações prejudiciais aos agentes públicos envolvidos em atos de corrupção. Para tornar-se escândalo, a divulgação das informações deve atender a dois requisitos principais: 1 ) as informações devem ser previamente escondidas; e 2) a fonte deve ser confiável e crível. Nesse ponto, Balán (2009) conecta ambas as dimensões às estruturas de incentivos associada aos insiders do governo, ou seja, dada a posição privilegiada ao acesso a informações (não disponibilizadas ao público em geral), esses atores se encontram em condições mais propensas a divulgar os malfeitos dos políticos.

No estágio seguinte, as informações são divulgadas tornando-se disponíveis ao público mais amplo. Nesse ponto, a publicização do escândalo pode ser favorecida pelo caráter investigativo e informativo da mídia, e de outras agências de controle do governo atentas às denúncias de corrupção. Na terceira fase, após a reação social referente ao escândalo, este ganha intensidade a partir das contra-alegações, o que pode incitar novas revelações e investigações posteriores. Outro aspecto destacado por Balán (2009) diz respeito aos incentivos que os insiders da coalizão governista têm para vazar informações. Diferentes circunstâncias políticas e interesses individuais podem conduzir para o vazamento dessas informações: um agente político pode vazar informações comprometedoras com o intuito de desestabilizar seu colega de coalizão e com isso tomar seu cargo, algo como puxar o tapete (leap-frog). Em outra situação, um agente político que esteja insatisfeito com sua posição na estrutura de distribuição de poder, por achar que tem pouco espaço (recurso político), pode visualizar melhores oportunidades se passar para o lado da oposição. Para justificar sua saída e desmoralizar a coalizão governista, esse agente pode vazar informações gerando um escândalo de corrupção, algo como incendiar o navio antes de saltar dele (jump-ship).

O ambiente político desempenha papel fundamental no cálculo racional do vazador de informações. Em um ambiente de oposição forte, os membros do governo

\footnotetext{
8 Miguel (2007) aborda o papel que a mídia desenvolve como difusora e transformadora do discurso político. Parte da literatura tem se debruçado sobre o processo de midiatização da política, especificamente no que diz respeito ao papel da mídia na democracia (Rubim, 2000; Miguel, 2000, 2007; Chaia, 2004; Porto, 1996, 2004).

${ }^{9} \mathrm{O}$ conceito de corrupção adotado aqui alinha-se ao empregado por Nye (1967).

${ }^{10}$ Cf. Thompson (2002); Lowi (1988).
} 
BOA NOITE, E BOA SORTE: DETERMINANTES DA DEMISSÃO DE MINISTROS ENVOLVIDOS EM ESCÂNDALOS DE CORRUPÇÃO

tenderão a amoitar os malfeitos de seus pares, entretanto, um agente político pode visualizar o vazamento de informações como janela de oportunidade para abandonar a coalizão e se integrar à oposição com vistas a desempenhar algum papel de prestígio na cena política. Contudo, esse tipo de fenômeno é mais difícil de acontecer, uma vez que existe uma tendência maior a abafar a denúncia do que a torná-la pública, haja vista que nada garante que a oposição irá conceder o espaço político almejado. Nesses termos, uma forte oposição age como uma restrição à estratégia do leap-frog. Por outro lado, em um ambiente de oposição fraca, os mecanismos de competição intrapartidário podem operar através de denúncias de corrupção com a intenção de puxar o tapete do aliado político. Nesse contexto, as denúncias tendem a não desestabilizar o governo, mas apenas a provocar a queda de alguns membros, possibilitando assim uma reconfiguração da estrutura de distribuição de poder no interior da coalizão governista.

Parte da literatura reconhece que em democracias liberais há um campo fértil à promoção de escândalos políticos, devido a algumas características próprias do sistema, a saber: a) competição política acirrada; b) importância dos custos reputacionais; c) relativa autonomia da imprensa; e d) campo político aberto (Markovits e Silverstein, 1988; Thompson, 2002). Essas características são bem ressaltadas por Melo (2012) ao discutir de forma geral por que alguns malfeitos se tornam escândalos e outros não. 0 autor aponta a competição política como razão explicativa para a incidência de escândalos de corrupção no Brasil, haja vista que em contextos com alto grau de competição política há fortes incentivos à oferta de denúncias, tanto por parte da oposição e de instituições de checks and balances quanto pela própria base de sustentação parlamentar, caracterizando o "fogo amigo".

Dada a estrutura do presidencialismo de coalizão no Brasil ${ }^{11}$, a divulgação de informações sigilosas faz parte de uma estrutura de incentivos e custos que norteiam distintos atores políticos. Nesse sentido, aqueles parlamentares que recebem cargos podem desfrutar de benefícios, como o aumento da satisfação ideológica, vantagens eleitorais, prestígio e intensificação da representação (Pereira, Power e Raile, 2009). A distribuição das pastas ministeriais nas mãos dos partidos da base de apoio do presidente traz consigo a ideia de que esses partidos (na pessoa do ministro) estarão em melhores condições quanto ao acesso a recursos e à capacidade de influenciar nas decisões de políticas públicas. De fato, as estratégias no gerenciamento da formação dos gabinetes são mais complexas do que o simples preenchimento de funções. Raile, Pereira e Power (2011) apontam que o presidente implementa estratégias que utilizam múltiplas ferramentas, uma vez que a formação dos ministérios seria a grande estrutura na qual os

\footnotetext{
${ }^{11}$ Expressão originalmente cunhada por Abranches (1988). Uma vasta literatura tem se debruçado sobre essa forma de governo político, ver: Lamounier e Meneguello (1986), Reis (1988), Shugart e Carey (1992), Kinzo (1993), Linz (1994), Mainwaring (1999), Ames (2001), Carvalho (2003), Santos (2003), Figueiredo e Limongi (2006).
} 
pork barrel ${ }^{12}$ agiriam ajustando as negociações de acordo com as circunstâncias pontuais. Desse modo, o Executivo opera através de uma estratégia integrada que equilibra transferências políticas (pastas ministeriais), transferências financeiras (pork lícito ou ilícito) e concessões de preferências por políticas no interior das restrições sistêmicas.

Em meio a essa tentativa de equalização dos interesses, espera-se que a maior proximidade ideológica entre o partido do ministro e o partido da chefia do Executivo favorecerá a existência de uma melhor sintonia entre a ação do ministro e a expectativa do presidente. Inversamente, o ministro que pertença a um partido ideologicamente mais distante do partido do presidente fatalmente possuirá ações/opiniões mais distantes e consequentemente deverá ter suas ações acompanhadas mais de perto. Outro desdobramento dessa distância ideológica diz respeito à consequente menor tolerância por parte do presidente a malfeitos ${ }^{13}$ daqueles ministros cujos partidos estão mais distantes ideologicamente. Nesse limite, tais mecanismos políticos podem oferecer explicações mais robustas acerca da probabilidade de permanência no cargo de um político do alto escalão do governo envolvido em escândalo político.

A partir da literatura analisada, foram elaboradas três hipóteses para a explicação da demissão ou não de ministros envolvidos em escândalos de corrupção no primeiro governo Dilma Rousseff:

H1. Maior quantidade de notícias sobre escândalos de corrupção impacta positivamente na responsividade ante o malfeito, ou seja, demissão do ministro denunciado.

H2. O tamanho da representação parlamentar do partido do ministro denunciado em escândalo de corrupção na Câmara impacta positivamente na probabilidade da saída do ministro, uma vez que o horizonte temporal dos deputados é mais curto, o que pode gerar maior disputa por espaço/recurso e "puxadas de tapete".

H3. A proxy distância ideológica entre o partido do ministro e o partido do presidente indica que quanto maior for essa diferença, dada a heterogeneidade da supercoalizão, menor será a tolerância da presidência a possíveis malfeitos do ministro.

\footnotetext{
12 O termo pork barrel segue o conceito utilizado por Lowi (1963) no que se refere à forma de alocação de recursos na arena de políticas públicas distributivas.

13 Entenda-se "malfeitos" como o envolvimento do ministro em ações ilícitas, a exemplo de casos de corrupção política.
} 


\section{Apresentando os dados}

\section{Duração e intensidade dos escândalos de corrupção}

Embora a onda de escândalos de corrupção tenha se intensificado no início do segundo mandato presidencial de Dilma Rousseff, ainda não se compara aos momentos de crises vivenciados nos 17 primeiros meses de mandato, em 2011. A resposta relativamente rápida a essa onda de escândalos destoa do padrão verificado nos governos anteriores, ou seja, em um curto espaço de tempo houve a demissão de uma significativa parcela do corpo ministerial.

Nesse sentido, a escolha desse estudo de caso da experiência brasileira recente se torna relevante, na medida em que busca analisar a dinâmica entre atores políticos, mídia e accountability política. Para tanto, foram lidas e catalogadas 677 notícias dos jornais: Folha de S. Paulo, O Estado de S. Paulo e O Globo, do período de $1^{0}$ de janeiro de 2011 a 25 de maio de $2012^{14}$. A base de dados foi construída a partir de notícias sobre os escândalos de corrupção extraídas do portal eletrônico Deu no Jornal, que, por sua vez, compila todas as matérias relacionadas a corrupção publicadas nos principais jornais e revistas do país ${ }^{15}$. As notícias sobre escândalos de corrupção foram distribuídas por ministro, destacando o período em que o agente público permaneceu no cargo a partir da publicização da denúncia de corrupção até a data de sua saída da pasta ministerial. No Quadro 1 estão listados os ministros envolvidos em escândalos de corrupção ao longo do corte temporal:

\footnotetext{
${ }^{14}$ A escolha dos respectivos jornais deve-se por suas colocações no ranking estabelecido pelo índice médio de circulação de jornais pagos no país. Justifica-se ainda pela pesquisa anualmente elaborada pelo Instituto FSB Comunicações, com dados consolidados para o ano de 2011, com os deputados federais para saber quais são os principais veículos utilizados por eles. A pesquisa demonstra que $63 \%$ dos deputados federais que responderam à pesquisa (340 dos 513 deputados federais) têm os jornais como principal fonte de informação diária. Essa pesquisa ainda observou que os jornais mais lidos pelos deputados são Folha de $S$. Paulo, com $72 \%$ dos deputados, seguida de O Globo, com 36\%, e O Estado de S. Paulo, com 30\%. Nesse sentido, acredita-se que os jornais selecionados na pesquisa fornecem um conjunto de informações que balizam o cálculo político de parte do eleitorado de classe média no país.

${ }^{15}$ Disponível em: <http://www.deunojornal.org.br/>. Acesso em: 20 set. 2012.
} 
Quadro 1

Ministros envolvidos em escândalos de corrupção no corte temporal da pesquisa (10 de janeiro de 2011 a 25 de maio de 2012)

\begin{tabular}{|l|c|c|c|c|}
\hline \multicolumn{1}{|c|}{ Ministro } & Ministério & Partido & $\begin{array}{c}\text { Data de ingresso } \\
\text { no cargo }\end{array}$ & Data de saída \\
\hline Alfredo Nascimento & Transportes & PR & $01 / 01 / 2011$ & $06 / 07 / 2011$ \\
\hline Antônio Palocci & Casa Civil & PT & $01 / 01 / 2011$ & $07 / 06 / 2011$ \\
\hline Carlos Lupi & Trabalho & PDT & $01 / 01 / 2011$ & $04 / 12 / 2011$ \\
\hline $\begin{array}{l}\text { Fernando Bezerra } \\
\text { Coelho }\end{array}$ & Integração Nacional & PSB & $01 / 01 / 2011$ & - \\
\hline Fernando Pimentel & $\begin{array}{c}\text { Desenvolvimento, } \\
\text { Indústria e Comércio } \\
\text { Exterior }\end{array}$ & PT & $01 / 01 / 2011$ & - \\
\hline Ideli Salvatti & Relações Institucionais & PT & $01 / 01 / 2011$ & - \\
\hline Mário Negromonte & Cidades & PP & $01 / 01 / 2011$ & $02 / 02 / 2012$ \\
\hline Orlando Silva & Esportes & PC do B & $01 / 01 / 2011$ & $26 / 10 / 2011$ \\
\hline Pedro Novais & Turismo & PMDB & $01 / 01 / 2011$ & $14 / 09 / 2011$ \\
\hline Wagner Rossi & Agricultura & PMDB & $01 / 01 / 2011$ & $17 / 08 / 2011$ \\
\hline
\end{tabular}

Fonte: Elaborado pelos autores.

Observa-se que a onda de escândalos de corrupção no início do governo Dilma derrubou uma parcela não trivial do corpo ministerial. Esse período de crises e demissões foi iniciado com a denúncia de enriquecimento ilícito e tráfico de influência do então ministro-chefe da Casa Civil, Antônio Palocci (PT). Em meio ao escândalo, o ministro buscou explicar a trajetória financeira de seus negócios de consultoria em face das denúncias de venda ao fundo de pensão dos funcionários da Petrobras (Petros) de sua participação acionária na Holding Itaúsa em troca de doações à campanha eleitoral de Dilma Rousseff em 2010. Todavia, Palocci não conseguiu apoio político suficiente do PT para manter-se na pasta, tendo sido efetivada a sua saída em junho de 2011, após algumas semanas do início das denúncias.

O segundo ministro do alto escalão que saiu do governo seguindo nessa linha sucessória de onda de escândalos de corrupção foi o então ministro dos Transportes, Alfredo Nascimento (PR), cuja denúncia estava baseada em um esquema ilícito de arrecadação de recursos para o partido do ministro, $\mathrm{PR}$, através de irregularidades em licitações na pasta ministerial. Logo em seguida, em agosto do mesmo ano, foi decretada a saída de Wagner Rossi, o ministro da Agricultura no período, que foi denunciado por manter um esquema fraudulento na pasta, bem como por utilizar recursos públicos para financiamento de dívidas particulares. Nesse mesmo período, a Polícia Federal, através da operação de combate à corrupção denominada Voucher, desmantelou um esquema de desvio de verbas do Ministério do Turismo, que estava sob o comando do então ministro 
Pedro Novais (PMDB). No episódio, o ministro foi denunciado por participar do esquema, dentre outras denúncias, de desvio de dinheiro público para fins particulares.

Mário Negromonte (PP), então ministro das Cidades, foi o quinto a ser denunciado, por montar um esquema de pagamento de propina a deputados em troca de apoio político. O escândalo envolvendo o ex-ministro perdurou seis meses até sua saída ser efetivada em fevereiro de 2012. Por seu turno, o sexto denunciado foi o ministro dos Esportes, Orlando Silva (PCdoB), em razão de supostos desvios de recursos através de convênios irregulares com organizações não governamentais (ONGs) na pasta ministerial. Esse episódio teve significativa repercussão midiática, em virtude de o exministro ter feito inúmeras declarações em toda oportunidade possível, inclusive foi ao Congresso prestar depoimentos duas vezes. Porém, mesmo utilizando essa estratégia de defesa, Orlando Silva não conseguiu manter-se no controle da pasta, saindo poucas semanas após o surgimento das denúncias. Na sequência, o ministro do Trabalho, na época, Carlos Lupi (PDT), tornou-se o alvo de denúncias sobre irregularidades em convênios com ONGs vinculadas ao Ministério. Ao longo da publicização denunciativa, o ex-ministro também marcou uma forte presença nos noticiários diários, através de declarações acaloradas, a exemplo da expressão utilizada de que só deixava o cargo "abatido a bala". Todavia, sem muitos recursos de defesa, Lupi deixou o cargo em dezembro de 2011.

Todavia, três dos dez ministros denunciados em escândalos de corrupção não deixaram as pastas ministeriais, são eles: Ideli Salvatti (PT), então ministra da Pesca (posteriormente à frente da Secretaria de Direitos Humanos da Presidência da República); Fernando Bezerra Coelho (PSB), na época ministro da Integração Nacional (posteriormente senador da República pelo estado de Pernambuco); e Fernando Pimentel (PT), então ministro do Desenvolvimento, Indústria e Comércio Exterior (posteriormente governador do estado de Minas Gerais). Em janeiro de 2012, Fernando Bezerra Coelho, ministro da Integração Nacional, esteve vinculado ao escândalo sobre supostos favorecimentos ao estado de Pernambuco, através de direcionamento de verbas destinadas a catástrofes naturais. No mês seguinte, outras denúncias surgiram associando o ministro do Desenvolvimento, Indústria e Comércio Exterior, Fernando Pimentel, a um suposto enriquecimento ilícito através de atividades de consultoria que teria realizado. Em março do mesmo ano surgiu a denúncia sobre irregularidades na compra de 28 lanchas-patrulha que se encontram inoperantes por parte do Ministério da Pesca. Ideli Salvatti, então ministra da pasta no início do governo Dilma, foi envolvida no escândalo em razão da suposta relação entre o apoio financeiro concedido à sua campanha ao governo do estado de Santa Catarina, em 2010, e o favorecimento à empresa contemplada nessa tramitação financeira.

Quando analisada a trajetória política dos ministros envolvidos em escândalos de corrupção (Quadro 2), observa-se um padrão de vida pública extensa, com exceção para o caso do ex-ministro dos Esportes Orlando Silva, que faz parte do grupo dos jovens 
políticos com ascensão relativamente rápida, dado que antes de ser empossado ministro dos Esportes no segundo mandato do governo Lula, em meados de 2006, nunca havia disputado eleição para cargo público.

\section{Quadro 2 \\ Trajetória política dos ministros denunciados em escândalos de corrupção ${ }^{16}$}

\begin{tabular}{|c|c|}
\hline Ministros & Cargos eletivos \\
\hline Alfredo Nascimento & $\begin{array}{l}\text { Prefeito de Manaus - AM (1997-2004) / Senador - AM (2007- } \\
\text { 2014) / Ministro dos Transportes (2007-2011) }\end{array}$ \\
\hline Ideli Salvatti & $\begin{array}{l}\text { Deputada Estadual - SC (1995-2003) / Senadora - SC (2003- } \\
\text { 2011) / Ministra da Pesca e Aquicultura do Brasil (2011-2011) / } \\
\text { Ministra-chefe da Secretaria de Relações Institucionais (2011- } \\
\text { 2014) }\end{array}$ \\
\hline Orlando Silva & Ministro do Esporte (2006-2011) \\
\hline Fernando Bezerra & $\begin{array}{l}\text { Deputado Estadual - PE (1983-1987) / Deputado Federal - PE } \\
\text { (1987-1992) / Ministro da Integração Nacional (2011-2013) }\end{array}$ \\
\hline Wagner Rossi & $\begin{array}{l}\text { Deputado Estadual - SP (1983-1991) / Deputado Federal - SP } \\
\text { (1991-1999) / Ministro da Agricultura, Pecuária e Abastecimento } \\
(2010-2011)\end{array}$ \\
\hline Antônio Palocci & $\begin{array}{l}\text { Vereador de Ribeirão Preto - SP (1988-1989) / Deputado } \\
\text { Estadual - SP (1990-1992) / Prefeito de Ribeirão Preto - SP } \\
\text { (1993-1996; 2001-2002) / Deputado Federal - SP (1999-2000; } \\
\text { 2007-2011) / Ministro da Fazenda (2003-2006) / Ministro-chefe } \\
\text { da Casa Civil (2011-2011) }\end{array}$ \\
\hline Pedro Novais & $\begin{array}{l}\text { Deputado Estadual - MA (1979-1983) / Deputado Federal - MA } \\
(1991-2015) \text { / Ministro do Turismo (2011-2011) }\end{array}$ \\
\hline Carlos Lupi & $\begin{array}{l}\text { Deputado Federal - RJ (1991-1995) / Ministro do Trabalho e } \\
\text { Emprego (2007-2011) }\end{array}$ \\
\hline Fernando Pimentel & $\begin{array}{l}\text { Prefeito de Belo Horizonte - MG (2001-2009) / Ministro do } \\
\text { Desenvolvimento, Indústria e Comércio Exterior (2011-2014) }\end{array}$ \\
\hline Mário Negromonte & $\begin{array}{l}\text { Deputado Estadual - BA (1991-1995) / Deputado Federal - BA } \\
(1995-2015) / \text { Ministro das Cidades (2011-2012) }\end{array}$ \\
\hline
\end{tabular}

Fonte: Elaborado pelos autores.

O Gráfico 1 mostra a disposição do tempo de vida pública dos ministros ao longo dos anos:

${ }^{16}$ O tempo de vida pública toma como ponto de partida o primeiro cargo eletivo que o agente público exerceu. 
Gráfico 1

Tempo de vida pública dos ministros (anos)

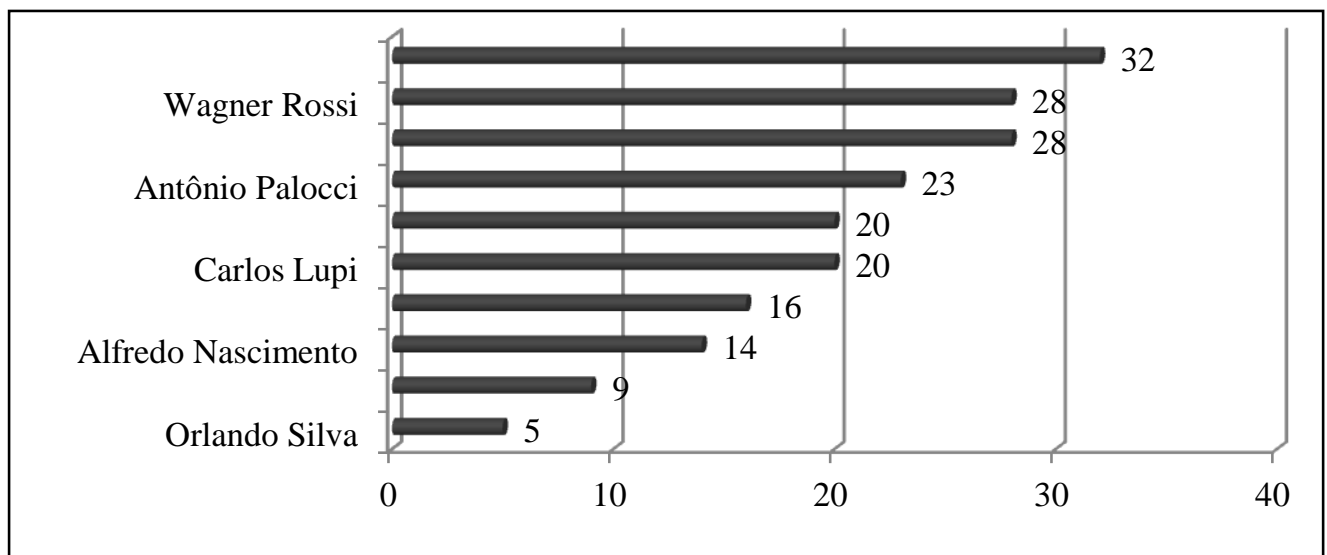

Fonte: Elaborado pelos autores.

O tempo médio de vida pública do alto escalão envolvido em escândalos de corrupção do governo Dilma representa 19,5 anos. Isso não é um dado irrelevante, uma vez que a função de ministro de Estado é uma escolha política por parte do Executivo que, por sua vez, está transferindo controle de pastas ministeriais para os partidos pertencentes à coalizão governista. Ou seja, pressupõe que os indicados para esse cargo sejam políticos de forte presença partidária e/ou projeção nacional, sendo peças importantes aos interesses no âmbito interno ao partido ao qual está vinculado.

O Gráfico 2 apresenta o número de matérias sobre os seus respectivos escândalos de corrupção por ministro veiculadas em cada um dos três jornais analisados no corte temporal da pesquisa (10 de janeiro de 2011 a 25 de maio de 2012). Essa informação possibilita mensurar a atenção que cada um dos três veículos de comunicação conferiu a cada ministro denunciado. É possível identificar que os ministros que mais atraíram a atenção da mídia de uma forma geral foram Antônio Palocci (145 matérias), Orlando Silva (120 matérias) e Carlos Lupi (121 matérias).

Por sua vez, o Gráfico 3 exibe o número de dias em que foram noticiadas matérias sobre escândalos de corrupção envolvendo o corpo ministerial. Esse gráfico permite visualizar o tempo de duração de cada um dos escândalos a partir do primeiro dia em que a denúncia foi publicizada até a saída (ou não) do ministro implicado. Verifica-se que os dois escândalos que mais duraram foram os de Fernando Pimentel, 30 dias, e Mário Negromonte, 33 dias. Entretanto, apesar de ambos os ministros terem tido ao longo de 30 dias notícias vinculadas aos respectivos escândalos, a intensidade com que essas notícias foram divulgadas foi reduzida se comparada a outros casos. 


\section{Gráfico 2}

Número de matérias veiculadas pelos jornais selecionados por ministro ( $1^{\circ}$ de janeiro de 2011 a 25 de maio e 2012)

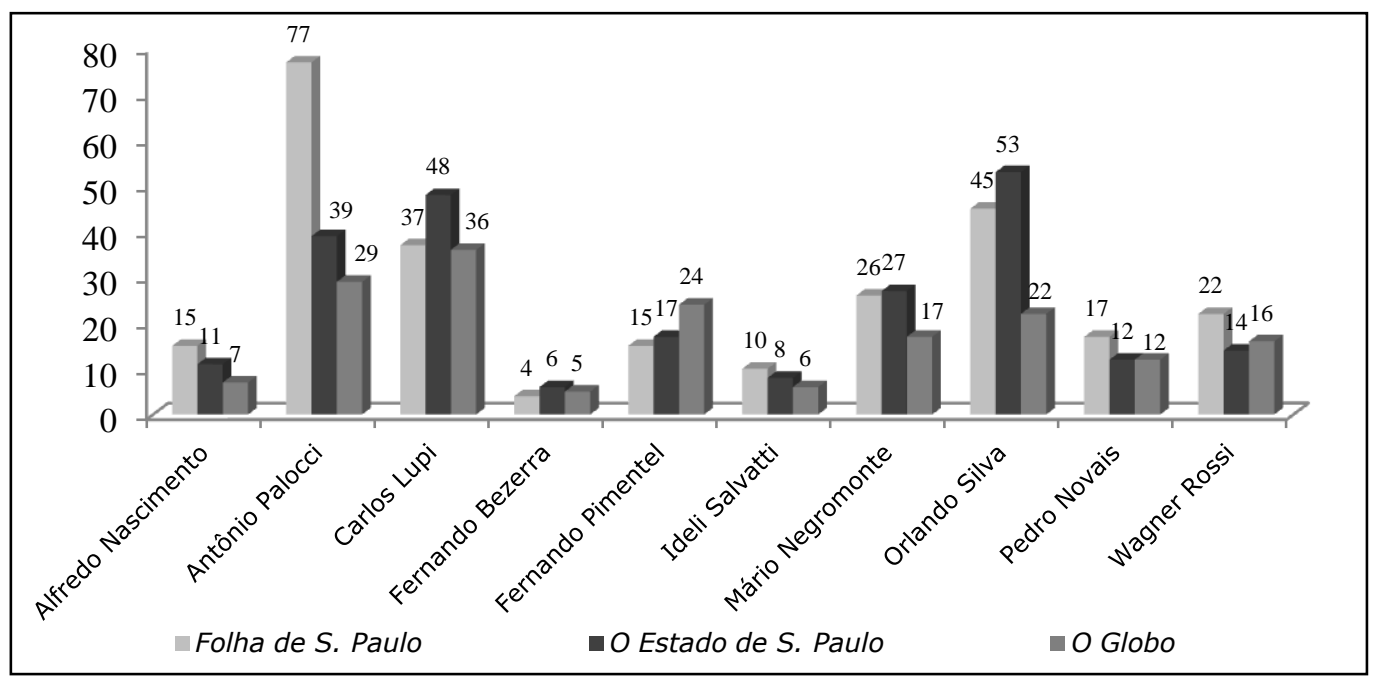

Fonte: Elaborado pelos autores.

Gráfico 3

Número de dias em que foram veiculadas matérias sobre escândalos de corrupção envolvendo os ministros

(10 de janeiro de 2011 a 25 de maio de 2012)

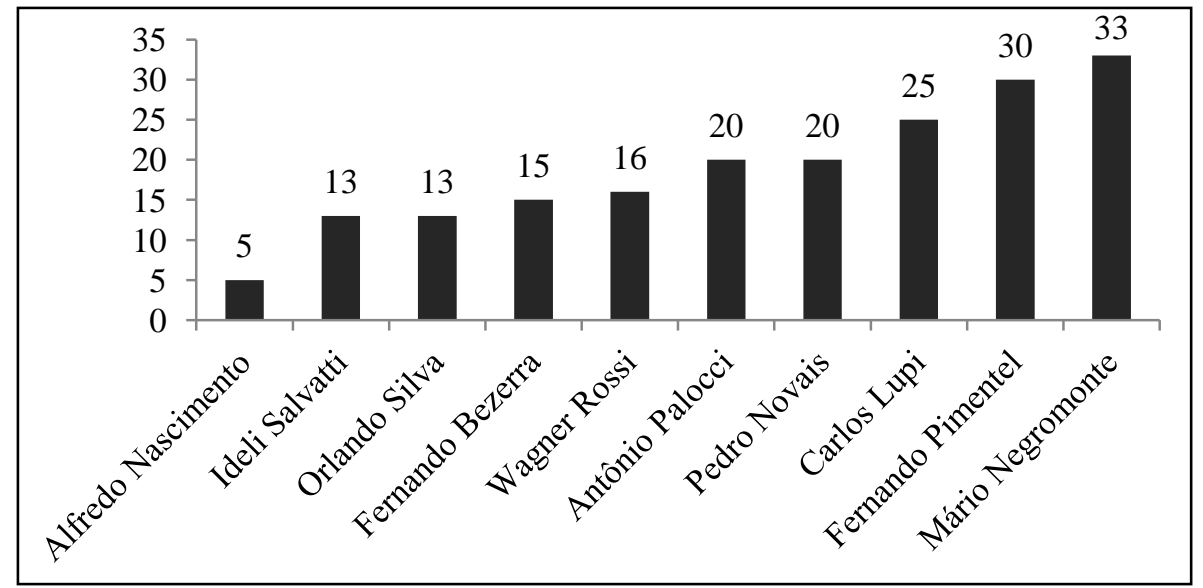

Fonte: Elaborado pelos autores. 
A quantidade média de matérias por dia fornece uma medida que leva em consideração a duração ${ }^{17}$ e a intensidade ${ }^{18}$ dos escândalos de corrupção reportados pelos jornais selecionados. Através disso é possível identificar que o escândalo envolvendo o ex-ministro Alfredo Nascimento, que foi o mais breve (5 dias, ver Gráfico 3), foi um dos que apresentaram maior quantidade média de matérias (intensidade), 6,6. Por sua vez, o ministro que apresentou a maior quantidade média no tocante à publicização do escândalo foi o ex-ministro Orlando Silva, com 9,2 matérias ao longo dos 13 dias em que o escândalo foi reportado pela mídia. Entretanto, vale ressaltar que os três jornais não forneceram a mesma atenção para os mesmos escândalos, o que pode ser observado através do desvio-padrão da cobertura realizada pelos jornais em tela. O caso de Antônio Palocci é emblemático por possuir o desvio-padrão mais elevado. O escândalo envolvendo esse ministro despertou atenção especial do jornal Folha de S. Paulo, que dedicou 77 matérias a esse caso em específico, ao passo que o jornal $O$ Estado de $S$. Paulo lhe dedicou apenas 39 e O Globo, 29 matérias. Ou seja, a Folha de S. Paulo conferiu significativa intensidade ao escândalo associado a Palocci, uma vez que a quantidade de matérias é maior que o somatório publicizado pelos jornais $O$ Estado de $S$. Paulo e O Globo (68 matérias).

Tabela 1

Indicadores selecionados

\begin{tabular}{|l|c|c|c|c|}
\hline \multicolumn{1}{|c|}{ Ministro } & $\begin{array}{c}\text { Quantidade } \\
\text { média de } \\
\text { matérias por dia }\end{array}$ & $\begin{array}{c}\text { Tamanho do partido } \\
\text { do ministro no } \\
\text { Congresso (\%) }\end{array}$ & $\begin{array}{c}\text { Perda do } \\
\text { mandato }\end{array}$ & $\begin{array}{c}\text { Desvio-padrão } \\
\text { da cobertura } \\
\text { dada pelos } \\
\text { jornais }\end{array}$ \\
\hline $\begin{array}{l}\text { Alfredo } \\
\text { Nascimento }\end{array}$ & 6,6 & 7,1 & Sim & 4 \\
\hline Antônio Palocci & 7,3 & 16,7 & Sim & 25,3 \\
\hline Carlos Lupi & 4,8 & 5,2 & Sim & 6,6 \\
\hline $\begin{array}{l}\text { Fernando } \\
\text { Bezerra Coelho }\end{array}$ & 1,0 & 5,6 & Não & 1 \\
\hline $\begin{array}{l}\text { Fernando } \\
\text { Pimentel }\end{array}$ & 1,9 & 16,7 & Não & 4,7 \\
\hline Ideli Salvatti & 1,8 & 16,7 & Não & 2 \\
\hline $\begin{array}{l}\text { Mário } \\
\text { Negromonte }\end{array}$ & 2,1 & 7,4 & Sim & 5,5 \\
\hline Orlando Silva & 9,2 & 2,5 & Sim & 16 \\
\hline Pedro Novais & 2,1 & 16,7 & Sim & 2,8 \\
\hline Wagner Rossi & 3,3 & 16,7 & Sim & 4,1 \\
\hline
\end{tabular}

Fonte: Elaborada pelos autores.

17 Refere-se à quantidade de dias em que houve matérias vinculadas aos respectivos escândalos analisados.

${ }^{18}$ Refere-se à quantidade de matérias por jornal sobre cada ministro denunciado. 
Competição política e gerenciamento da coalizão no primeiro governo Dilma Rousseff

Outro aspecto relevante à questão da accountability democrática refere-se ao papel do Legislativo no tocante à permanência (ou não) do ministro denunciado em escândalo de corrupção. Mais especificamente no que diz respeito ao estudo em tela, convém analisar a composição do Congresso brasileiro, destacando o tamanho dos partidos políticos, assim como o tamanho da bancada de apoio ao governo vis-à-vis a bancada de oposição, e assim buscar explicações para a forma como essas forças agiram no fenômeno aqui analisado.

Tabela 2

Composição do Congresso no primeiro governo Dilma (\%)

\begin{tabular}{|c|c|c|c|}
\hline Partidos & Coalizão & Senadores & Deputados \\
\hline PT & Aliança governista & 16,0 & 17,2 \\
\hline PRB & Aliança governista & 2,5 & 1,6 \\
\hline PDT & Aliança governista & 6,2 & 5,5 \\
\hline PMDB & Aliança governista & 22,2 & 15,4 \\
\hline $\mathrm{PP}$ & Aliança governista & 4,9 & 8,0 \\
\hline PR & Aliança governista & 4,9 & 8,0 \\
\hline PSB & Aliança governista & 3,7 & 6,6 \\
\hline PSC & Aliança governista & 1,2 & 3,3 \\
\hline PCdoB & Aliança governista & 2,5 & 2,9 \\
\hline PTC & Aliança governista & 0,0 & 0,2 \\
\hline PSDB & Oposição & 14,8 & 10,3 \\
\hline DEM & Oposição & 8,6 & 8,4 \\
\hline PTB & Oposição & 7,4 & 4,1 \\
\hline PPS & Oposição & 1,2 & 2,3 \\
\hline PMN & Oposição & 1,2 & 0,8 \\
\hline PTdoB & Oposição & 0,0 & 0,6 \\
\hline PV & Não coligados & 0,0 & 2,9 \\
\hline PSOL & Não coligados & 2,5 & 0,6 \\
\hline PHS & Não coligados & 0,0 & 0,4 \\
\hline PRP & Não coligados & 0,0 & 0,4 \\
\hline PRTB & Não coligados & 0,0 & 0,4 \\
\hline PSL & Não coligados & 0,0 & 0,2 \\
\hline
\end{tabular}

Fonte: Elaborada pelos autores a partir de dados extraídos no portal eletrônico do Congresso Nacional. Disponível em: http://www.congressonacional.leg.br. Acesso em: 30 set. 2012. 
A Tabela 2 exibe a participação percentual dos partidos políticos presentes no Congresso nacional distribuídos entre a Câmara de Deputados e o Senado Federal. Observa-se a formação de uma coalizão majoritária dos partidos aliados ao governo no âmbito do Congresso. O Gráfico 4 demonstra que na Câmara de Deputados o governo detém mais de $2 / 3$ das cadeiras da casa legislativa, o que possibilita a ele (partidos pertencentes à coalizão) aprovar e/ou modificar leis que necessitam de no mínimo $2 / 3$ dos votos sem a necessidade de dialogar com a oposição. Já no que diz respeito ao Senado, a vantagem do governo não chega a ser tão ampla, mas a base aliada ainda detém $64,2 \%$ das cadeiras.

Gráfico 4

Composição do Congresso no governo primeiro Dilma (\%)

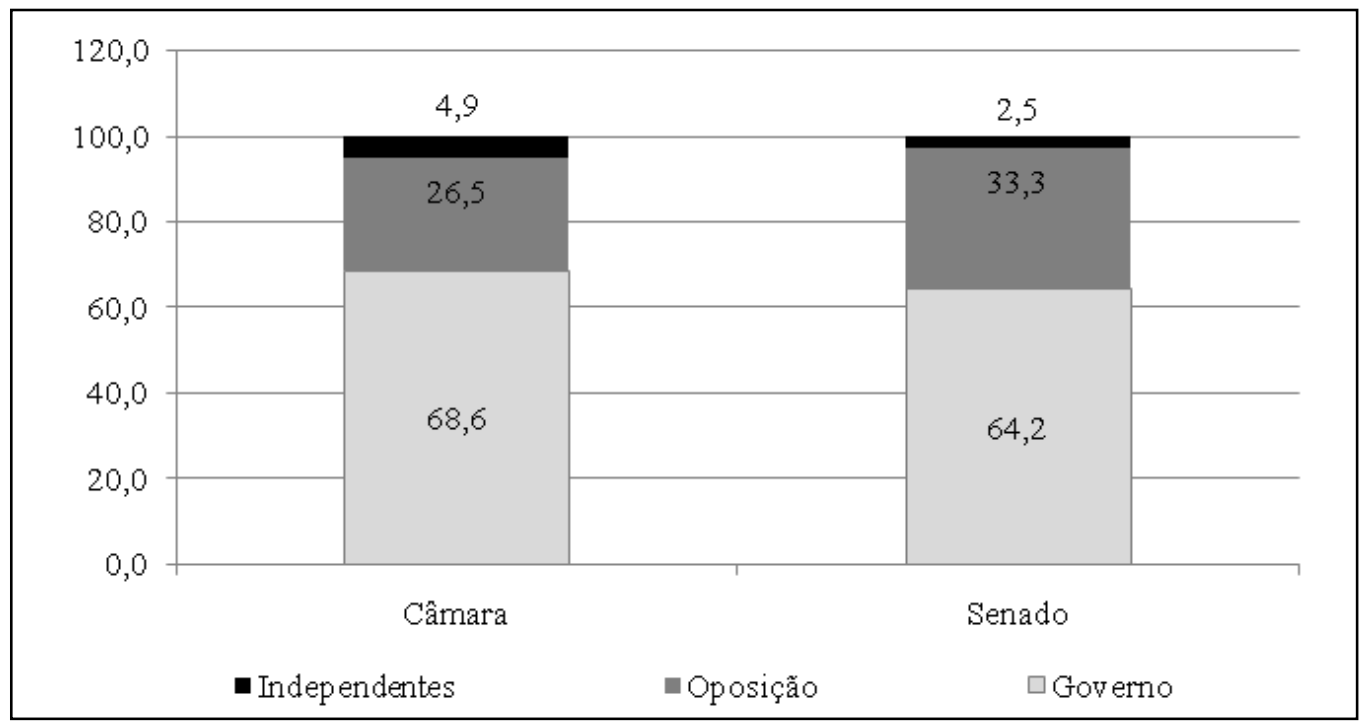

Fonte: Elaborado pelos autores a partir de dados extraídos no portal eletrônico do Congresso Nacional. Disponível em: http://www.congressonacional.leg.br. Acesso em: 30 set. 2012.

O Gráfico 5 apresenta a distância ideológica dos diversos partidos da coalizão de sustentação do governo Dilma em relação ao $\mathrm{PT}^{19}$, partido da presidente. É possível identificar, por exemplo, que Alfredo Nascimento, pertencente ao PR, permaneceu no cargo apenas cinco dias após o início das denúncias de seu envolvimento em atividades ilícitas, e seu partido, dentro da coalizão, é o que está mais distante ideologicamente do PT. O que pode indicar uma menor tolerância em relação às falhas daqueles ministros pertencentes aos partidos mais distantes ideologicamente. Quando analisado o caso de

\footnotetext{
${ }^{19}$ A partir da classificação ideológica realizada por Zucco e Lauderdale (2011), foi calculada a distância entre o score do PT e os dos demais partidos da coalizão governista.
} 
Palocci (PT), percebe-se um padrão diferente: do início do escândalo até a sua saída do cargo foram 20 dias de notícias denunciando o seu envolvimento em atividades ilícitas. É possível identificar a construção de uma superbase de apoio do governo Dilma. Nesse ambiente de oposição fragilizada e um alto grau de heterogeneidade na coalizão governista, é de se esperar que ocorram alguns escândalos com o intuito de alterar a distribuição de poder dentro da coalizão.

\section{Gráfico 5}

Distância ideológica dos partidos da coalizão em relação ao PT

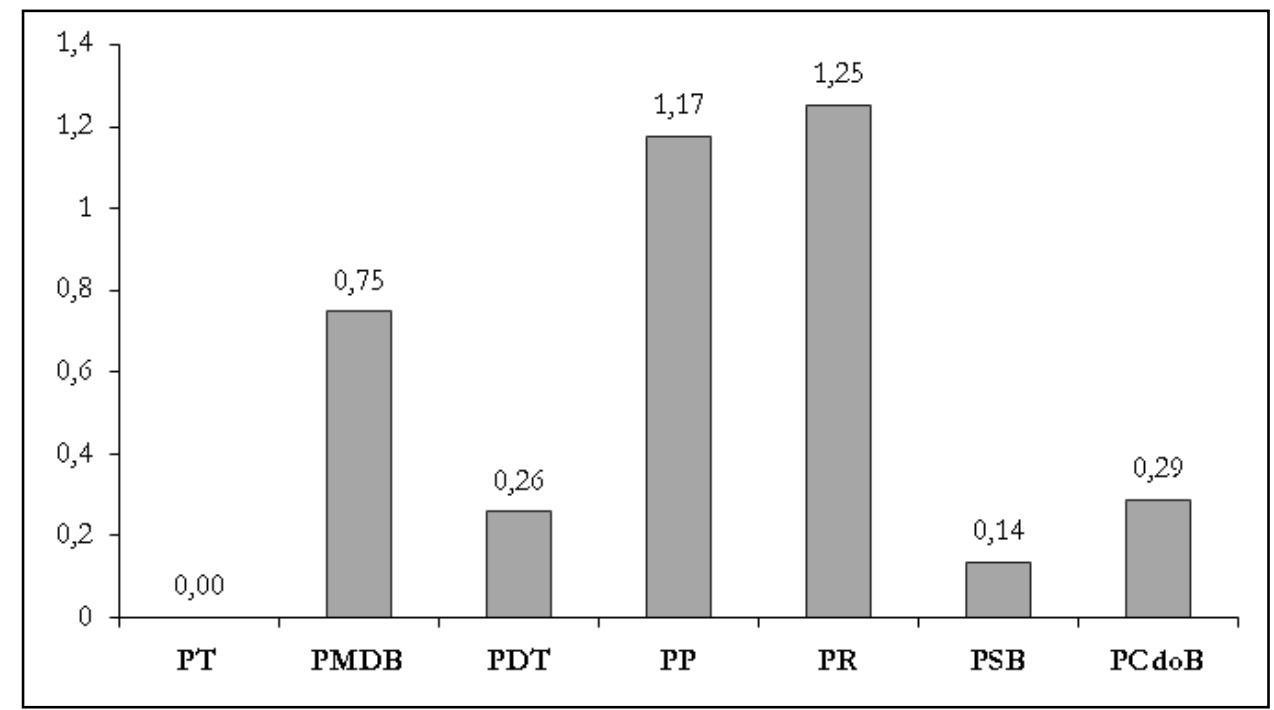

Fonte: Elaborado pelos autores a partir de Zucco e Lauderdale (2010).

\section{Determinando a causalidade}

Através da análise descritiva das variáveis selecionadas para este artigo foi possível identificar que a quantidade de matérias sobre escândalos de corrupção denunciando ministros do primeiro governo Dilma pode desempenhar um papel importante para a saída ou permanência no cargo dos ministros analisados. A variável relacionada ao tamanho da representação parlamentar na Câmara dos ministros denunciados mostrou-se interessante na estatística descritiva e possui um apelo teórico. Outra variável que deve ser levada em consideração diz respeito ao gerenciamento da coalizão governista, em que é calculada a distância ideológica dos diversos partidos em relação ao partido do presidente. Apesar de a estatística descritiva possibilitar uma primeira aproximação dos dados, ela não permite relações de causalidade nem de estimação da relação existente entre as variáveis selecionadas. Isso só é possível através da utilização de modelos de regressão. Através da utilização desses modelos será 
possível fornecer respostas à pergunta de pesquisa, a saber: como agiram as forças dos atores políticos para a saída (ou não) do ministro denunciado em escândalo de corrupção no primeiro governo Dilma Rousseff? Neste artigo, a saída (ou não) do ministro é a variável dependente, ao passo que notícias de corrupção, número de cadeiras do partido na Câmara e distância ideológica entre o partido do ministro e o partido da presidente constituem as variáveis independentes. Denomina-se aqui de notícias de corrupção o número de todas as reportagens associadas aos escândalos de corrupção por ministro, com intuito de analisar se a maior exposição midiática favorece a responsividade em relação às denúncias de corrupção. Por seu turno, o número de cadeiras do partido na Câmara é definido como a quantidade de cadeiras pertencentes ao partido do ministro denunciado no escândalo na Câmara dos Deputados. Essa variável busca identificar se um contexto de competição acirrada e curto horizonte temporal favorece a ocorrência de "puxadas de tapetes". Finalmente, a variável distância ideológica busca verificar se o fato de o ministro denunciado pertencer a um partido ideologicamente distante do partido da presidente the confere menor estabilidade no cargo. Destarte, essas variáveis independentes se relacionam com o modelo teórico-conceitual da accountability democrática no sentido de que capturam funções apontadas pela literatura sobre qualidade da democracia.

No Quadro 3 são apresentadas de forma sistematizada as variáveis utilizadas no modelo estatístico, bem como a relação causal esperada pelo modelo:

\section{Quadro 3}

Lista de variáveis adotadas e relações esperadas

\begin{tabular}{|l|c|c|}
\hline \multicolumn{1}{|c|}{ Variáveis } & Descrição & $\begin{array}{c}\text { Relação causal } \\
\text { esperada }\end{array}$ \\
\hline Saída do ministro & $\begin{array}{c}\text { Dummy para todos os ministros } \\
\text { (Saiu = 1; Não saiu = 0) }\end{array}$ & Variável dependente \\
\hline $\begin{array}{l}\text { Notícias de } \\
\text { corrupção }\end{array}$ & $\begin{array}{c}\text { Quantidade de notícias de } \\
\text { corrupção }\end{array}$ & + \\
\hline $\begin{array}{l}\text { Número de cadeiras } \\
\text { do partido na } \\
\text { Câmara }\end{array}$ & $\begin{array}{c}\text { Quantidade de cadeiras do partido } \\
\text { do ministro denunciado na Câmara } \\
\text { Federal }\end{array}$ & + \\
\hline Distância ideológica & $\begin{array}{l}\text { Distância ideológica do partido do } \\
\text { ministro em relação ao partido da } \\
\text { presidente }\end{array}$ & $\mathbf{+}$ \\
\hline
\end{tabular}

Fonte: Elaborado pelos autores.

O objetivo da análise estatística consiste em estimar um modelo probabilístico da relação causal entre as variáveis explicativas e a probabilidade de o ministro denunciado de corrupção deixar (ou não) o ministério que dirige, e/ou analisar em termos probabilísticos se determinada variável independente produz o evento acima mencionado. Assim, como a variável dependente é binária e a utilização de um modelo 
de probabilidade linear (MPL) não se ajusta ao desenho da pesquisa, já que a probabilidade condicional pode não estar inserida no intervalo fechado 0 e 1 , e os termos de erros não possuem distribuição normal, mas binomial e heterocedástico, optou-se pela adoção do modelo probit. Alternativamente o modelo Relogit desenvolvido por King e Zeng (1999) poderia ter sido adotado, entretanto, devido a limitações desse modelo, reconhecidas pelos próprios autores, o modelo probit mostrou-se mais adequado para esta pesquisa. Assim, formalmente, o modelo geral é definido como:

$$
y^{*}=x^{\prime} \beta+u
$$

Embora $y^{*}$ não seja observado, consideramos que

$$
y^{*}\left\{\begin{array}{l}
1 \text { se } y^{*}>0 \\
0 \text { se } y^{*} \leq 0
\end{array}\right.
$$

Assim, dados (1.1) e (1.2), temos:

$$
\begin{aligned}
\operatorname{Pr}(y=1) & =\operatorname{Pr}\left(x^{\prime} \beta+u>0\right) \\
& =\operatorname{Pr}\left(-u<x^{\prime} \beta\right) \\
& =\Phi\left(x^{\prime} \beta\right)
\end{aligned}
$$

Onde $\Phi($.) é função de distribuição normal padrão cumulativa e $\beta$ é o vetor de parâmetros das variáveis explicativas. Por sua vez, para facilitar a interpretação dos coeficientes estimados, recorreu-se ao efeito marginal médio definido como:

$$
\Phi\left(x^{\prime} \hat{\beta} / x_{i}=1\right)-\Phi\left(x^{\prime} \hat{\beta} / x_{i}=0\right)(1.3)
$$

Então o modelo estimado foi definido como sendo:

$$
\Phi\left(x^{\prime} \hat{\beta}\right)=\Phi\left(\hat{\beta}_{1}+\hat{\beta}_{2} Q n C+\hat{\beta}_{3} N u m C a d C+\hat{\beta}_{4} \text { DistIdeolPT }\right)
$$

A Tabela 3 apresenta o Modelo Probit utilizado para este artigo tendo como variável dependente: saída do ministro. 
Tabela 3

Modelo Probit - Variável dependente: saída do ministro

\begin{tabular}{|c|c|c|c|}
\hline Variáveis & Coeficientes & Erro-padrão & p-valor \\
\hline $\begin{array}{l}\text { Quantidade de } \\
\text { notícias de } \\
\text { corrupção }\end{array}$ & 0.1344 & 0.0426 & $0.0020 * * *$ \\
\hline $\begin{array}{l}\text { Número de } \\
\text { cadeiras na } \\
\text { Câmara }\end{array}$ & 0.0155 & 0.0090 & $0.0830 *$ \\
\hline $\begin{array}{l}\text { Distância } \\
\text { ideológica }\end{array}$ & 1.0671 & 0.5034 & $0.0340 * *$ \\
\hline Constante & -4.0257 & 0.9292 & $0.0000 * * *$ \\
\hline \multicolumn{2}{|c|}{$\begin{array}{l}\text { Observações: } \\
\text { Estatística de teste (LR) }\end{array}$} & & $\begin{array}{c}211 \\
10.70 \\
0.0135\end{array}$ \\
\hline \multicolumn{3}{|l|}{ Pseudo $R_{8}^{2}$} & 0.2018 \\
\hline \multicolumn{3}{|l|}{ Prob. $>\chi^{2}$} & $\begin{array}{l}4.15 \\
0.8431\end{array}$ \\
\hline
\end{tabular}

A estatística de teste Likehood Ratio (LR) aponta para a rejeição da hipótese nula de que todos os coeficientes do modelo são iguais a zero, no nível de $1 \%$ ( $p$-valor abaixo de 0,01$)$. Destarte, é possível afirmar que as estimações geradas pelo modelo adotado apresentam nível de robustez satisfatório.

Dito isso, observou-se que os sinais das variáveis explicativas apresentaram o resultado esperado, sendo todas estatisticamente significantes. A variável quantidade de notícias de corrupção (QnC) apresentou significância estatística no nível de $1 \%$ ( $p$-valor abaixo de 0,01), enquanto número de cadeiras na câmara (NumCadC) é significante estatisticamente no nível de $10 \%$ ( $p$-valor abaixo de 0,1 ) e distância ideológica (DistIdeoPT) apresentou significância estatística no nível de 5\% ( $p$-valor abaixo de $0,05)^{20}$.

Os achados empíricos possibilitam verificar que a quantidade de notícias sobre os escândalos de corrupção envolvendo ministros e o número de cadeiras do partido do ministro na Câmara dos Deputados têm a relação esperada pela literatura: de gerar

20 Com os coeficientes estimados no modelo o efeito marginal médio para cada variável explicativa selecionada ficou assim distribuído: "Quantidade de notícias de corrupção" $(0,01 \%)$, "Número de cadeiras na Câmara Federal" (0,01\%) e "Distância ideológica" (0,06\%). 
responsividade a partir do papel fiscalizatório da imprensa, bem como de intensificar a competição política em um ambiente de recursos limitados e horizonte temporal curto. Por fim, o fato de o ministro denunciado ser de um partido ideologicamente distante em relação ao partido da presidente Ihe confere maior instabilidade no cargo; em outros termos, haveria uma menor tolerância por parte da chefia do Executivo com os ministros denunciados em escândalos de corrupção quando estes forem membros de partidos mais distantes ideologicamente em relação ao $\mathrm{PT}^{21}$.

\section{Considerações finais}

Com base nas constatações verificadas neste artigo, foi possível fazer inferências sobre quais aspectos políticos (variáveis independentes) favorecem a saída (ou não) do ministro denunciado em escândalo de corrupção (variável dependente) ao longo do período destacado. Os achados obtidos pelo modelo estatístico utilizado indicam que maior número de matérias sobre os respectivos escândalos impactam positivamente na probabilidade do denunciado ser demitido. Obviamente, esse dado não é trivial, uma vez que não se desconsidera o papel que a mídia desempenha através da publicização ativa das denúncias de malfeitos dos agentes públicos, particularmente nesse estudo de caso. Porém, a crítica se dirige no sentido de que, para além dessa função, a imprensa escrita nacional, pelo menos os jornais selecionados, parece ainda não apresentar o potencial normativo ressaltado pela literatura da accountability democrática ${ }^{22}$.

Por fim, qual o significado de tais achados para o debate da qualidade da democracia? Acredita-se que o saldo é parcialmente positivo, na medida em que apontam que esses mecanismos de accountability - notícias sobre escândalos de corrupção - podem operar no sentido de restringir, ou pelo menos de constranger, os malfeitos de políticos que chegam a pertencer ao alto escalão do governo. Entretanto, ao fim e ao cabo, o corporativismo no Congresso bem como o protecionismo aos partidos mais próximos ideologicamente do partido da presidente parecem prejudicar a eficiência da responsividade democrática, que se torna amplamente dificultada pelo quadro de impunidade generalizada geralmente percebida nos casos de escândalos de corrupção envolvendo a elite política brasileira. Contudo, vale destacar que, apesar de se tratar de um fenômeno circunscrito num curto espaço/tempo, não se desqualifica a importância de

\footnotetext{
${ }^{21}$ Entretanto vale salientar as limitações do modelo aqui empregado, em função do curto período de tempo e pequeno número de observações.

${ }_{22} \mathrm{Em}$ que medida a accountability pode ser reforçada pela exposição dos desvios de atores políticos reportados pela mídia? Os escândalos midiáticos, por exemplo, são resultado de um jornalismo investigativo e possuem pontos positivos e negativos. Se, por um lado, geram aumento na fiscalização das atividades políticas e entram no cálculo do risco de exposição de qualquer negociação política, ou seja, podem aumentar a prudência ao comportamento inadequado, por outro, podem levar à generalização dos "maus exemplos" de políticos, resultando em descrença nas instituições, vistas como inoperantes e custosas. O papel da mídia ainda é ambíguo, mas não significa que não tenha importância na arena pública.
} 
BOA NOITE, E BOA SORTE: DETERMINANTES DA DEMISSÃO DE MINISTROS ENVOLVIDOS EM ESCÂNDALOS DE CORRUPÇÃO

analisá-lo e se espera que possa instigar pesquisas futuras buscando tornar mais robustas as explicações sobre os desdobramentos dos escândalos de corrupção no recente governo brasileiro.

Cletiane Medeiros Araújo - Mestre em ciência política pela UFPE, doutoranda do Programa de Pós-Graduação em Ciência Política da UFPE, bolsista CNPq. E-mail: <cletiane.araujo@hotmail.com>.

Saulo Felipe Costa - Mestre em ciência política pela UFPE e em relações internacionais pela UEPB, doutorando do Programa de Pós-Graduação em Ciência Política da UFPE, bolsista Capes. E-mail: <s.felipe@hotmail.com>.

Ítalo Fittipaldi - Doutor em ciência política (UFPE) e professor de ciência política na UFPB. E-mail: <italofittipaldi@yahoo.com>.

\section{Referências bibliográficas}

AbRANCHeS, S. H. "Presidencialismo de coalizão: o dilema institucional brasileiro". Dados, n 31 , 1988.

Ames, B. The deadlock of democracy in Brazil. Ann Arbor: University of Michigan Press, 2001.

BALÁN, M. "Competition by denunciation: the political dynamics of corruption scandals in Argentina and Chile". In: Annual Meeting of the Midwest Political Science Association, Chicago, April 2-5, 2009.

CARvalho, N. R. E no início eram as bases: geografia política do voto e comportamento legislativo no Brasil. Rio de Janeiro: Revan, 2003.

CHAIA, V. Jornalismo e política: escândalos e relações de poder na Câmara Municipal de São Paulo. São Paulo: Hacker, 2004.

Cox, G. W.; MccubBins, M. D. The institutional determinants of economic policy outcomes. In: Haggard, S.; Mccubbins, M. D. (eds.). Presidents, parliaments and policy. New York: Cambridge University, 2001.

DiAmOND, L. "Thinking about hybrid regimes". Journal of Democracy, vol. 13, n 2, p. 21-35, 2002.

DiAmond, L.; Morlino, L. "The quality of democracy: an overview". Journal of Democracy, vol. $15, \mathrm{n}^{\circ}$ 4, p. $20-31,2004$.

2005.

. (eds.). Assessing the quality of democracy. Baltimore: Johns Hopkins University Press,

Figueiredo, A.; Limongi, F. Poder de agenda na democracia brasileira: desempenho do governo no presidencialismo pluripartidário. In: SOARES, A. D. G.; RENNó, R. L. (orgs.). Reforma política: lições da história recente. Rio de Janeiro: Editora FGV, p. 249-280, 2006.

KING, K.; ZENG, L. Logistic regression in rare events data. Department of government. Cambridge: Harvard University, 1999. 
Kinzo, M. D. G. Radiografia do quadro partidário brasileiro. São Paulo: Fundação Konrad Adenauer, 1993.

KRUEGER, A. O. "The political economy of the rent-seeking society". The American Economic Review, vol. 64, n०3, p. 291-303, 1974.

Lamounier, B.; Meneguello, R. Partidos políticos e consolidação democrática. São Paulo: Brasiliense, 1986.

LINZ, J. J. Presidential or parliamentary democracy: does it make a difference?. In: LINZ, J. J.; VAlenzuela, A. (eds.). The failure of presidential democracy: the case of Latin America. Baltimore: Johns Hopkins University Press, 1994.

LowI, T. "American business, public policy, case studies and political theory". World Politics, vol. 16, n०4, p. 677-715, 1963.

. Foreword. In: MARKOVITS e SILVERSTEIN (eds.). The politics of scandal: power and process in liberal democracies. New York: Holmes \& Meier, 1988.

MAINWARING, S. Sistemas partidários em novas democracias: o caso do Brasil. Rio de Janeiro: FGV, 1999.

MANIN, B. The principles of representative government. Cambridge: Cambridge University Press, 1997.

MARKovits, A. S.; Silverstein, M. Introduction: power and process in liberal democracies. In: . (eds.). The politics of scandal: power and process in liberal democracies. Nova York: Holmes \& Meier, 1988.

Melo, M. A. "O viés majoritário na política comparada: responsabilização, desenho institucional e qualidade democrática". Revista Brasileira de Ciências Sociais, São Paulo, vol. 22, n 63, p. 11-29, fev. 2007.

27 jan. 2012.

"Por que alguns malfeitos tornaram-se escândalos?". Valor Econômico, São Paulo, p. a8,

Miguel, L. F. "Um ponto cego nas teorias da democracia: os meios de comunicação". BIB - Revista

Brasileira de Informação Bibliográfica em Ciências Sociais, Rio de Janeiro, n 49, p. 51-77, 2000.

Curitiba, 2007

"A mídia e o declínio da confiança na política". In: Anais do Encontro da Compós, 16.

MoIsÉs, J. A. "Cultura política, instituições e democracia: Lições da experiência brasileira". Revista Brasileira de Ciências Sociais, vol. 23, nº 66, p. 11-44, 2008.

Moreno, E.; Crisp, B.; Shugart, M. The accountability deficit in Latin America. In: MAINWARING, S.; WelnA, C. (eds.). Democratic accountability in Latina America. New York: Oxford University, 2003.

MORLINO, L. "What is a 'good' democracy? Theory and empirical analysis". In: Annals of Conference "The European Union, Nations State, and the Quality of Democracy - Lessons from the Southern Europe", University of California, 2002.

NYE, J. S. "Corruption and political development: a cost-benefit analysis". American Political Science Review, vol. 61, p. 417-427, 1967.

O'DONNELL, G. "Accountability horizontal e novas poliarquias". Lua Nova, n 44, 1998. 
BOA NOITE, E BOA SORTE: DETERMINANTES DA DEMISSÃO DE MINISTROS ENVOLVIDOS EM ESCÂNDALOS DE CORRUPÇÃO

Pereira, C.; Power, T.; RaIle, E. Presidencialismo de coalizão e recompensas paralelas: explicando o escândalo do mensalão. In: InACIO, M.; RENNó, L. (eds.). Legislativo brasileiro em perspectiva comparada. Minas Gerais: Editora da UFMG, p. 207-340, 2009.

Peruzzotti, E.; Smulovitz, C. Controlando la política. Buenos Aires: Temas Grupo Editorial, 2002.

Porto, M. A crise de confiança na política e suas instituições: a mídia e a legitimidade da democracia. In: BARQUERO, M. (org.). Condicionantes da consolidação democrática: ética, mídia e cultura política. Porto Alegre: Editora da Universidade da UFRGS, p. 41-64, 1996.

Enquadramentos da mídia e política. In: RuBIM, A. A. (org.). Comunicação e política: conceitos e abordagens. Salvador: EdUFBa, p. 73-104, 2004.

PowELL, G. B. "The chain of responsiveness". Journal of Democracy, vol. 15, no 4, p. 91-105, 2004.

PRZEWORSKI, A.; STOKES, S. Citizen information and government accountability: what must citizens know to control government. New York University \& University of Chicago, multicopiado, 1995.

Raile, E.; Pereira, C.; Power, T. "The executive toolbox: building legislative support in a multiparty presidential regime". Political Research Quarterly, vol. 64, p. 323-334, 2011.

ReIS, F. W. Partidos, ideologia e consolidação democrática. In: ReIs, F. W., O'Donnell, G. (orgs.). A democracia no Brasil: dilemas e perspectivas. São Paulo: Vértice, 1988.

Rubim, A. A. C. "A contemporaneidade como idade mídia". Revista Interface, Comunicação, Saúde, Educação, vol. 4, n 7, p. 25-36, 2000.

SANTOS, F. O Poder Legislativo no presidencialismo de coalizão. Belo Horizonte: Editora UFMG, 2003. p. 29-110.

SEN, A. Development as freedom. Nova York: Knopf, 1999.

SHIN, D. C. Democratization: perspectives from global citizenries, In: DALTON, R.; KLINGEMANN, H-D. (eds.). The Oxford handbook of political behavior. Oxford: Oxford, 2007.

Shugart, M. S.; CAReY, J. M. Presidents and Assemblies: constitutional design and electoral dynamics. Cambridge: Cambridge University Press, 1992.

Thompson, J. B. O escândalo político: poder e visibilidade na era da mídia. Petrópolis: Vozes, 2002.

TULLOCK, G. "Welfare costs of tariffs, monopoly and theft". Western Economic Journal, p. 291-303, 1967.

ViannA, L. J. W. A democracia e os três poderes no Brasil. Rio de Janeiro/Belo Horizonte: Editora da UFMG/Iuperj/Faperj, 2002.

WefForT, F. C. Qual democracia?. São Paulo: Cia. das Letras, 1992.

Zucco, C.; LAUderdale, B. "Ideal point estimates of Brazilian legislators (1989-2011)". Legislative Studies Quarterly, vol. XXXVI, no 3, August 2011. 


\title{
Resumo
}

Boa noite, e boa sorte: determinantes da demissão de ministros envolvidos em escândalos de corrupção no primeiro governo Dilma Rousseff

Quais os determinantes para demissão de ministros? Este artigo analisa a onda de escândalos de corrupção envolvendo ministros do primeiro governo Dilma Rousseff. O desenho de pesquisa combina estatística descritiva e análise multivariada para testar as hipóteses de que notícias sobre escândalos políticos, competição política e gerenciamento da coalizão impactam positivamente na probabilidade de o ministro denunciado deixar a pasta ministerial. O estudo foi realizado a partir da construção de uma base de dados, para a qual foram coletadas 677 notícias de três jornais de larga circulação nacional, a saber: Folha de S. Paulo, O Estado de S. Paulo e O Globo, ao longo dos 17 primeiros meses do governo. Os resultados apontam que quanto maior o número de matérias sobre os escândalos de corrupção do ministro denunciado maior a probabilidade de ele ser demitido. Espera-se, através deste estudo de caso, contribuir para a agenda de pesquisa sobre a relação escândalos políticos/instituições democráticas/accountability, buscando situar esse fenômeno na democracia brasileira recente.

Palavras-chave: escândalos; notícia; corrupção; governo; accountability política

\begin{abstract}
Good night, and good luck: determining the dismissal of ministers involved in corruption scandals in the first government Dilma Rousseff

What determines the dismissal of Ministers? This article analyzes the lot of corruption scandals involving ministers of the first Dilma Rousseff's administration. The research design combines descriptive statistics and multivariate analysis for test of the hypothesis that news political scandals, political competition, and management of the government's coalition have a positive effect on the odds of the accused minister to leave the Cabinet. This paper based in construction of a database with 677 headlines of the three major national newspapers: Folha de S. Paulo, O Estado de S. Paulo, and $O$ Globo, over the first seventeen months of Rousseff's administration. The results show that the greater number of news articles covering the corruptions scandals involving the minister in question, the greater the probability that she/he will be fired. We desire that this case study contribute to the research agenda on the relationship political scandals/democratic institutions/accountability trying to place this phenomenon in recent Brazilian democracy.
\end{abstract}

Keywords: scandals; news; corruption; political accountability

\section{Resumen}

Buenas noches, y buena suerte: la determinación de la dimisión de los ministros involucrados en escándalos de corrupción en el primer gobierno Dilma Rousseff

¿Cuáles son los factores determinantes en el despido de ministros? En este artículo se analiza la ola de escándalos de corrupción que involucran a ministros del primer Gobierno de Dilma Rousseff. El diseño de la investigación combina estadística descriptiva y análisis multivariado para probar la hipótesis de que las noticias sobre escándalos políticos, la competencia política y la gestión de la coalición tienen un impacto positivo sobre la probabilidad de que el ministro acusado deje la cartera ministerial. El estudio se realizó desde la construcción de una base de datos, que se han recolectado en 677 noticias de tres periódicos nacionales de gran circulación, a saber: Folha de S. Paulo; O Estado de S. Paulo; y O Globo, durante los primeros diecisiete meses del gobierno. Los resultados muestran que cuanto mayor sea el número de noticias sobre escándalos de corrupción del ministro denunciado, mayor será la probabilidad de que sea despedido. Se espera a través de este estudio de caso, contribuir a la agenda de investigación sobre la relación escándalos políticos/instituciones democráticas/accountability buscando situar este fenómeno en la democracia brasileña reciente. 
BOA NOITE, E BOA SORTE: DETERMINANTES DA DEMISSÃO DE MINISTROS ENVOLVIDOS EM ESCÂNDALOS DE CORRUPÇÃO

Palabras clave: escándalos; noticias; corrupción; gobierno; accountability política

\section{Résumé}

Bonne nuit et bonne chance: la détermination de la révocation des ministres impliqués dans des scandales de corruption dans le premier gouvernement Dilma Rousseff

Qu'est ce qui détermine la destitution de Ministres? Cet article analyse la vague de scandales de corruption impliquant des ministres du premier gouvernement de Dilma Rousseff. L'esquisse de cette recherche combine des statistiques descriptives et une analyse multivariée pour tester I'hypothèse selon laquelle les nouvelles sur les scandales politiques, la compétition politique, et la gestion de la coalition gouvernementale ont un effet positif sur la probabilité que le ministre accusé quitte son cabinet. Cette étude a été réalisée à partir de la construction d'une base de données comprenant 677 nouvelles extraites de trois quotidiens nationaux de grande diffusion: Folha de $S$. Paulo, O Estado de S. Paulo et $O$ Globo, au cours des dix-sept premiers mois de l'administration Rousseff. Les résultats montrent que plus nombre de nouvelles sur les scandales de corruption du ministre dénoncé est élevé, plus il est probable qu'il soit démis de ses fonctions. À travers cette étude de cas, on espère contribuer à l'agenda de recherche sur la relation entre scandales politiques / institutions démocratiques / accountability, en essayant de situer ce phénomène dans la récente démocratie brésilienne.

Mots-clés: scandales; nouvelles; corruption; accountability politique

Artigo submetido à publicação em março de 2015.

Versão final aprovada em novembro de 2015. 